\title{
Pleiotropic effects of RsmA and RsmE proteins in Pseudomonas fluorescens 2P24
}

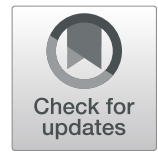

Yang Zhang ${ }^{1+}$, Bo Zhang ${ }^{1+}$, Haiyan $\mathrm{Wu}^{1}$, Xiaogang $\mathrm{Wu}^{1^{*}}$, Qing Yan ${ }^{2^{*}}$ and Li-Qun Zhang ${ }^{3^{*}}$

\begin{abstract}
Background: Pseudomonas fluorescens 2P24 is a rhizosphere bacterium that produces 2,4-diacetyphloroglucinol (2,4-DAPG) as the decisive secondary metabolite to suppress soilborne plant diseases. The biosynthesis of 2,4-DAPG is strictly regulated by the RsmA family proteins RsmA and RsmE. However, mutation of both of $r s m A$ and $r s m E$ genes results in reduced bacterial growth.

Results: In this study, we showed that overproduction of 2,4-DAPG in the rsmA rsmE double mutant influenced the growth of strain 2P24. This delay of growth could be partially reversal when the phID gene was deleted or overexpression of the ph/G gene encoding the 2,4-DAPG hydrolase in the rsmA rsmE double mutant. RNA-seq analysis of the $r$ smA rsmE double mutant revealed that a substantial portion of the $P$. fluorescens genome was regulated by RsmA family proteins. These genes are involved in the regulation of 2,4-DAPG production, cell motility, carbon metabolism, and type six secretion system.

Conclusions: These results suggest that RsmA and RsmE are the important regulators of genes involved in the plantassociated strain 2P24 ecologic fitness and operate a sophisticated mechanism for fine-tuning the concentration of 2,4-DAPG in the cells.
\end{abstract}

Keywords: Pseudomonas fluorescens, RsmA/RsmE, 2,4-DAPG, Biofilm, Motility

\section{Background}

Bacteria use a complex interconnecting mechanism to recognize and adapt to changes in their environment and reprogram numerous cellular processes in response to physiological homeostasis. An important element in this complex regulatory network is the Gac/Rsm cascade pathway [1]. This pathway is conserved in numerous Gramnegative bacteria and mediates the post-transcriptional regulation of diverse genes required for bacterial virulence and metabolism [2]. These include genes for the expression of extracellular enzymes [3], carbon storage compounds [4],

\footnotetext{
*Correspondence: 4146308505@outlook.com; qing.yan@montana.edu; zhanglq@cau.edu.cn

${ }^{\dagger}$ Yang Zhang and Bo Zhang contributed equally to this work.

${ }^{1}$ College of Agriculture, Guangxi University, Nanning 530004, China

${ }^{2}$ Department of Plant Sciences and Plant Pathology, Montana State

University, Bozeman 59717, USA

${ }^{3}$ College of Plant Protection, China Agricultural University, Beijing 100193, China
}

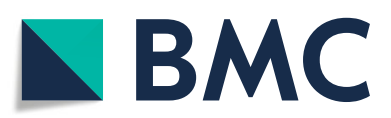

(c) The Author(s). 2020 Open Access This article is licensed under a Creative Commons Attribution 4.0 International License, which permits use, sharing, adaptation, distribution and reproduction in any medium or format, as long as you give appropriate credit to the original author(s) and the source, provide a link to the Creative Commons licence, and indicate if changes were made. The images or other third party material in this article are included in the article's Creative Commons licence, unless indicated otherwise in a credit line to the material. If material is not included in the article's Creative Commons licence and your intended use is not permitted by statutory regulation or exceeds the permitted use, you will need to obtain permission directly from the copyright holder. To view a copy of this licence, visit http://creativecommons.org/licenses/by/4.0/ The Creative Commons Public Domain Dedication waiver (http://creativecommons.org/publicdomain/zero/1.0/) applies to the data made available in this article, unless otherwise stated in a credit line to the data.

motility [5], the formation of biofilm [6], and the production of secondary metabolites and virulence factors $[7,8]$. Signal transduction initially involves the GacS/GacA twocomponent system which consists of the histidine kinase protein GacS and its cognate response regulator GacA. Upon interaction with unknown signals, the membrane sensor GacS autophosphorylates and activates the GacA by phosphorylation. Phosphorylated GacA positively controls transcription initiation of one or more small non-coding RNAs (sRNA) genes, depending on the bacterial species, such as $r \operatorname{sm} X, r s m Y$ and $r s m Z$ in Pseudomonas protegens CHA0 [9]. A conserved upstream activating sequence (UAS) is found to be necessary for GacA protein to activate the expression of these sRNAs [10]. These sRNAs exhibit high affinity for the CsrA/RsmA family protein. The CsrA/ RsmA family protein can inhibit translation or stability of transcripts of its target genes by binding to sites overlapping the SD sequence or ribosome binding sites of target 
mRNAs, thus influencing ribosome access [11]. In addition, varying numbers of RsmA orthologs have been described in different bacteria and these proteins exhibit distinct binding affinities to sRNAs and show distinct roles in particular strain [12-15].

P. fluorescens 2P24, a rhizospheric bacterium originally isolated from the take-all decline soil, has been investigated for its ability to produce the secondary metabolite 2,4-diacetylphloroglucinol (2,4-DAPG), which contributes to the protection of various crop plants against soil borne disease caused by many plant pathogens [16]. The biosynthetic pathway of 2,4-DAPG has been clarified in several Pseudomonas strains. The 2,4-DAPG locus includes the four biosynthetic genes phlACBD that are transcribed as a single operon and is directly involved in the catalytic process of 2,4-DAPG production [17]. The first step in 2,4-DAPG biosynthesis is the formation of phloroglucinol (PG) from three units of malonyl-coenzyme A (malonyl-CoA) by the type III polyketide synthase PhlD [18]. The products of phlACB genes are together required for the transacetylation of PG to monoacetylphloroglucinol (MAPG) and then 2,4-DAPG [19].

Since the high concentration of 2,4-DAPG is toxic to the producing bacterium, biosynthesis of 2,4-DAPG is subtly modulated by complex regulatory networks in response to abiotic and biotic factors, and cell physiological status $[20,21]$. The $p h l F$ and $p h l H$ genes, code for the pathway-specific transcriptional regulators of the production of 2,4-DAPG [19, 22]. Besides PhlF and PhlH, the Gac/Rsm cascade pathway plays a critical role in the production of 2,4-DAPG [1]. In P. fluorescens 2P24, the RsmA and RsmE proteins directly repress the translation of phlACBD mRNA, whereas four sRNAs RsmX, RsmX1, RsmY, and RsmZ derepress the translation of phlACBD mRNA by sequestering the RsmA and RsmE proteins, thereby inducing the production of 2,4-DAPG [15].

In this study, we found that RsmA and RsmE proteins contribute to bacterial growth advantages in $P$. fluorescens 2P24. Deletion of both of $\operatorname{rsm} A$ and $r s m E$ genes could impair growth rate and cell density, whereas the growth rate and cell density was partially restored in the rsmA rsmE phlD triple mutant compared with that of the wild-type strain, suggesting that high levels of 2,4DAPG in the cells could influence the growth of the rsmA rsmE double mutant. In addition, we demonstrated the role of the RsmA family proteins on type six secretion system (T6SS), swimming motility, and biofilm formation in P. fluorescens.

\section{Results}

High concentration of 2,4-DAPG in the cells impaired the growth of the rsmA rsmE double mutant

Previous study showed that the growth of the $r s m A$ rsmE double mutant was severely impaired compared with the wild-type strain 2P24. Since high levels of 2,4DAPG was toxic to the producing bacterium [20], to assess if the growth of the rsmA rsmE double mutant was impaired by the overdose of 2,4-DAPG in the cells, we overexpressed the phlG gene which encoding the 2 , 4-DAPG hydrolase and then measured the growth of $2 \mathrm{P} 24$ and its derivatives. As expected, introduction of the phlG gene cloned in the pRK415 plasmid (p415phlG), into the rsmA rsmE double mutant, resulted in repression of 2,4-DAPG production (Fig. 1a). The growth rate of the rsmA rsmE double mutant with $\mathrm{p} 415$ phlG could be partially restored to that of the wild-type strain 2P24 (Fig. 1b). Furthermore, by deleting the phlD gene in the $r \operatorname{sm} A \operatorname{rsmE}$ double mutant, the growth curve of the rsmA rsmE phlD triple mutant was significantly improved compared to that of the rsmA rsmE double mutant although was slightly lower compared to the wild-type strain 2P24 or the phlD mutant (Fig. 1c). Thus, these data suggested that overproduction of 2,4-DAPG contributes to the reduced growth of the $\operatorname{rsmA} r s m E$ double mutant.

\section{RNA sequencing reveals the $P$. fluorescens RsmA and RsmE regulon}

To insight into the role of RsmA and RsmE in P. fluorescens, RNA sequencing (RNA-seq) was performed to define the RsmA and RsmE regulon of P. fluorescens. The genes that are significantly downregulated or upregulated are summarized in Table S1A \& S1B. We defined the genes that showed a $>2$-fold change of expression as differentially expressed genes (DEGs). In the $r s m A$ rsmE double mutant, 621 genes were upregulated and 304 genes were downregulated compared to the wild-type strain (Table S1A \& S1B).

Based on the RNA-seq results, we observed that the expression of genes in phl operon (phlACBD) was increased by 145 to 587 -fold (Table S1). To verify the complex regulatory role of $r s m A$ and $r s m E$ on the production of 2,4DAPG, we measured the expression of phlG and phlF in the $r s m A$ rsmE double mutant, respectively. Transcriptional fusion assays showed that both of the expression of phlG and phlF were significantly increased in the $r s m A$ rsmE double mutant compared with that in the wild-type strain (Fig. 2). These results indicated a sophisticated role for the RsmA family proteins RsmA and RsmE in the production of 2,4-DAPG in P. fluorescens.

Among the genes upregulated in the $\operatorname{rsm} A$ rsmE double mutant, 21 encoded proteins that are associate with type six secretion system (T6SS), which is known as an important mechanism in interactions and pathogenesis against bacterial and eukaryotic cells. In addition, the RNA-seq data revealed that a significant number of genes influenced by RsmA and RsmE were involved in fatty acid metabolism ( $f a d A$, 


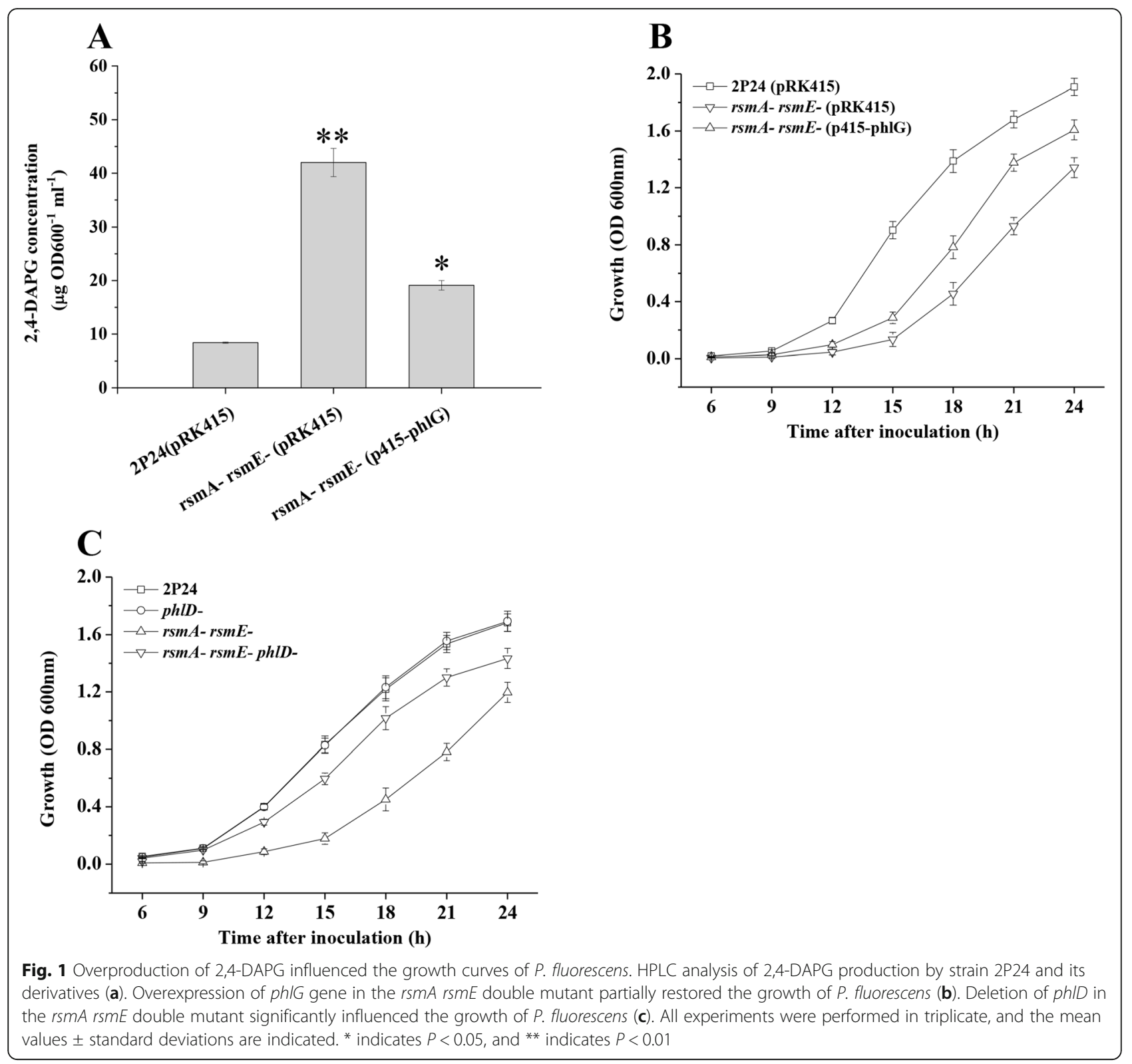

$f a d B, f a b G, f a d H, p s r A$ ), energy and carbon metabolism ( $g l p D, z w f, f a h A, g c d, g l t K)$, and cell motility (flaG, fliT, fliS, motA, motC, flgE). Collectively, our data suggested that RsmA and RsmE are the pleiotropic regulators of secondary metabolism, cell motility, and other physiological processes.

\section{RsmA and RsmE negatively regulated the type six secretion system (T6SS)}

Bacterial T6SS plays an important role in both virulence and inter-bacterial competition and provide advantages to T6SS active strains in polymicrobial habitats [23]. Since many genes related to T6SS were up-regulated in the $\operatorname{rsm} A$ rsmE double mutant, we assayed the effect of the RsmA family protein on the production of T6SS structure protein Hcp1. Consistent with the RNA-seq data in the $\operatorname{rsm} A$ rsmE double mutant, Western blot analysis showed that this mutant produced higher amount of the Hcp1 protein than wildtype strain P. fluorescens 2P24 (Fig. 3a). Previously studies showed that the T6SSs could inject the T6SS toxins into bacterial preys [24]. We then performed the antibacterial assays using E. coli carrying the plasmid pHSG299 as prey and P. fluorescens $2 \mathrm{P} 24$ or its derivatives as predators. Similar to the retS mutant which triggered the T6SS [25], The rsmA rsmE double mutant caused a significant increase in survival of $E$. coli (Fig. 3b). Taken together, our results indicate that RsmA and RsmE repress the T6SS activity and play an important role for the inter-bacterial competition. 


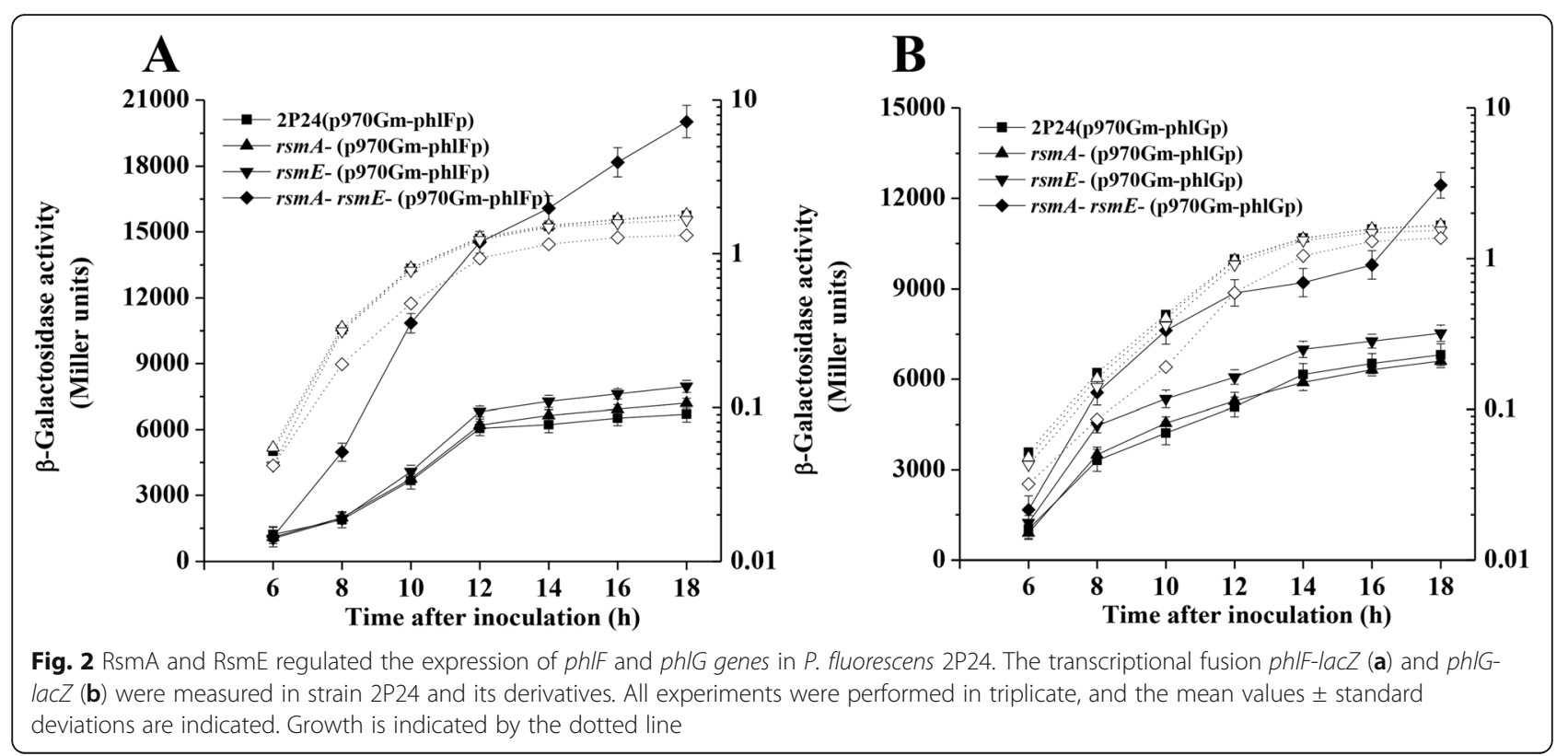

The effect of RsmA and RsmE on cell motility and biofilm formation

Analysis of the $r s m A \operatorname{rsm} E$ double mutant RNA-seq data showed that expression of 20 genes involved in flagella biosynthesis and assembly was significantly changed, indicated a decrease in cell motility. To confirm this result, the motility of strain $2 \mathrm{P} 24$ and its derivatives was measured. Compared to the wild-type strain, the swimming motility was reduced by $72 \%$ in the $r s m A$ rsmE double mutant (Fig. 4a). Motility is crucial in cell-to-cell adherence and attachment in early biofilm development. Whereas our data revealed a positive influence of the RsmA family proteins on biofilm formation (Fig. 4b). All observed phenotypes in the $r s m A$ rsmE double mutant could be partly complemented by introducing the plasmid pBBR-rsmE (Fig. 4). Taken together, these results demonstrated that

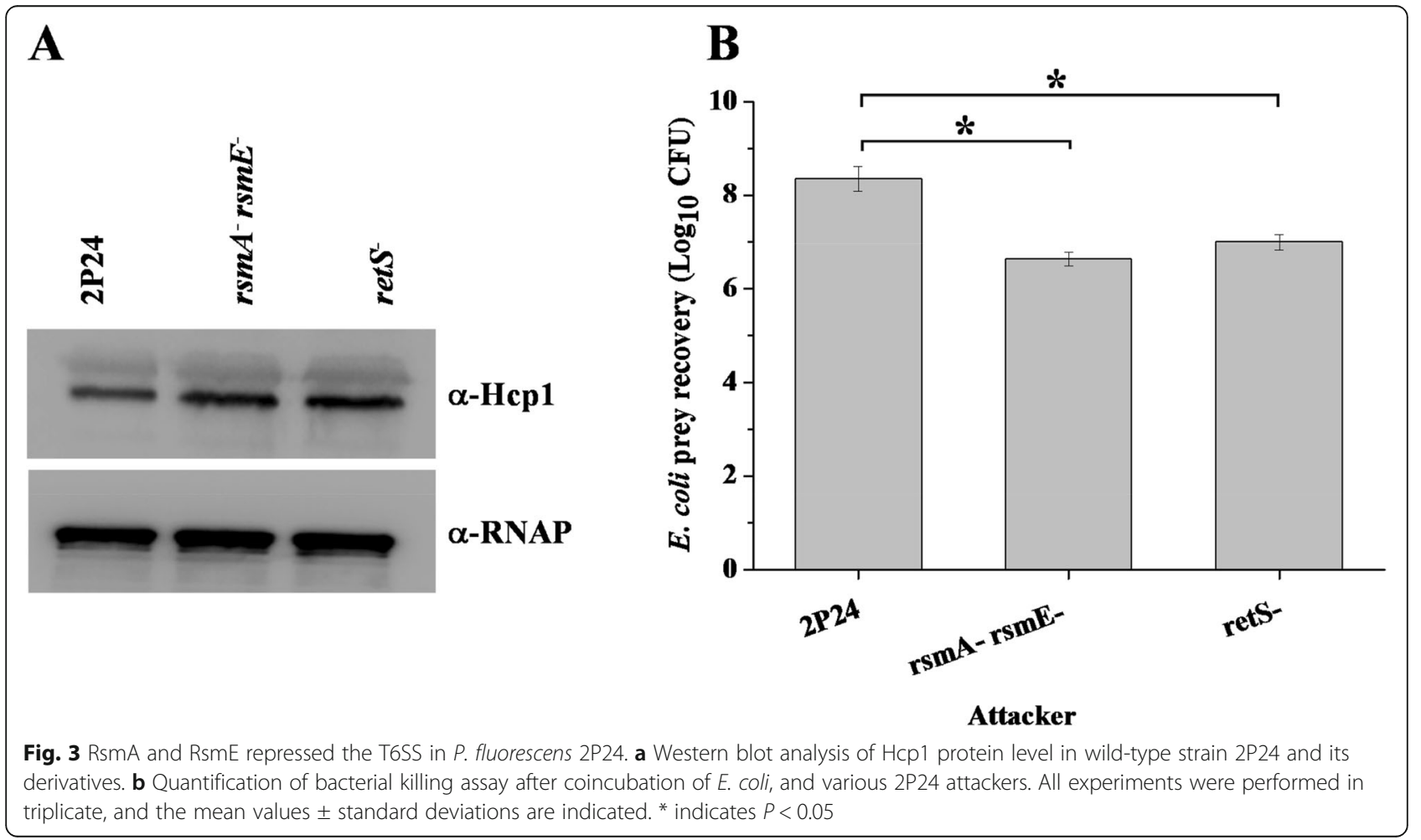




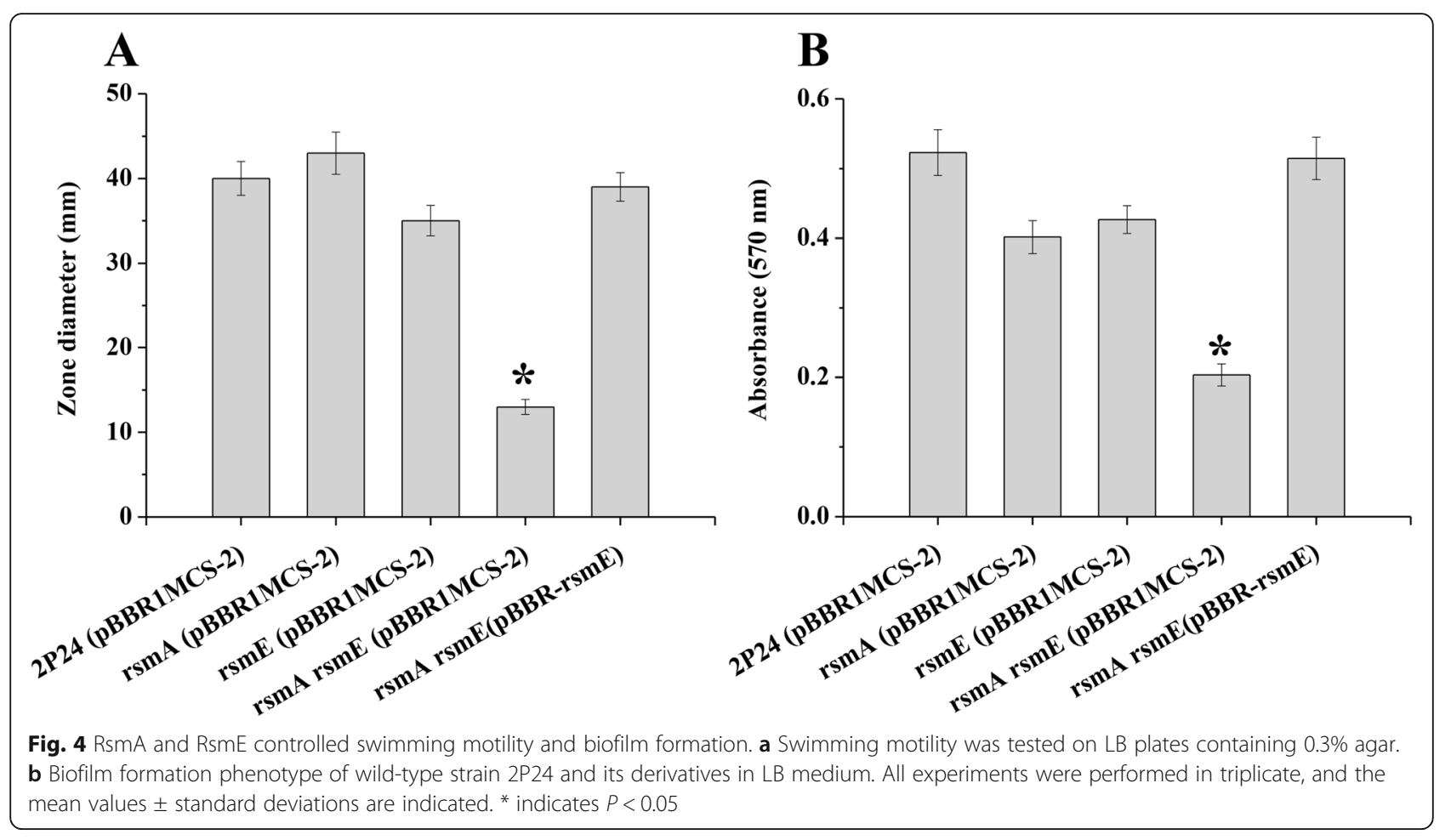

RsmA and RsmE are crucial for cell motility and biofilm formation in strain $2 \mathrm{P} 24$.

\section{Discussion}

Plant growth-promoting rhizobacteria could antagonize plant pathogenic fungi by the production of antimicrobial secondary metabolites, such as 2,4-DAPG. Although 2,4-DAPG has antifungal, antibacterial, anthelminthic, and phytotoxic properties, it has toxicity to the producing bacterium at high concentrations. Many regulatory elements, including Gcd [26], Hfq [27], PsrA [28], RopS [29], and PhlG which directly or indirectly influence 2,4DAPG biosynthesis, were regulated by the RsmA and RsmE (Table S1). The RsmA and RsmE proteins play an important role in regulating the production of antibiotic compound 2,4-DAPG, which is necessary for its biocontrol traits in P. fluorescens 2P24 [15]. In the present study, we revealed that regulation of the production of 2 , 4-DAPG by the RsmA family proteins RsmA and RsmE contributes to bacterial growth advantages.

The RsmA and RsmE proteins play a critical role for the production of 2,4-DAPG [1]. In P. fluorescens 2P24, RsmA and RsmE inhibited the expression of phlACBD at the translation level [15]. Varying numbers of RsmA orthologs have been identified in different Pseudomonas sp. [12, 14, 15]. The defects in the growth of the rsm mutants could be found in $P$. putida and $P$. syringae pv. tomato $[12,30]$. Although no evidence showed that deletion of both of $r s m A$ and $r s m E$ genes influenced the growth of $P$. protegens CHA0 which could produce several antibiotics, including 2,4-DAPG [31], our data showed that the defect of bacterial growth was observed in the $\operatorname{rsm} A \operatorname{rsmE}$ double mutant when compared with the wild-type strain 2P24 [15]. Interestingly, overexpression of phlG gene or deletion of phlD gene in the $r s m A$ rsmE double mutant partly restored the growth curve of strain 2P24 (Fig. 1). Transcriptional fusion assays further suggested that the expression of phlG and phlF genes were negatively regulated by RsmA and RsmE (Fig. 2), indicating that RsmA and RsmE could balance the concentration of 2,4-DAPG in the cells by fine-tuning the role of multiple regulators of the production of 2,4DAPG. The biosynthesis of 2,4-DAPG leads to lower bacterial growth rates due to the increased metabolic costs in the cells [22]. Deletion of phlD gene in the $r s m A$ rsmE double mutant could not completely restore the growth curve of strain 2P24 (Fig. 1), whereas the deficiency of the growth could be restored when the $r s m A$ rsmE double mutant was growth in minimal medium with glucose as a carbon source [15], indicating that RsmA and RsmE play an important role in central carbohydrate metabolism. Our RNA-seq analysis supported this hypothesis which identified several genes that are known to be involved in fatty acid metabolism, carbon metabolism, and pleiotropic molecule cyclic diguanylate production (Table S1). In addition, our data suggested that RsmA and RsmE are the global regulators in a complex regulatory network that provides advantages to strain $2 \mathrm{P} 24$ in 
polymicrobial environments. For instance, inactivation of both of $r s m A$ and $r s m E$ increased the levels of Hcp1 and provided a growth advantage against $E$. coli in $P$. fluoresces 2P24 (Fig. 3). These results were in agreement with the previously proposed role of $r s m A$ in affecting tssA1, tse6, and tsi4 [24]. Together, our data suggested that RsmA and RsmE might play a critical role in fine-tuning the concentration of 2,4-DAPG to maintain the metabolic homeostasis and improve the competitive advantages of $2 \mathrm{P} 24$ against other microbes living in or nearby the rhizosphere.

We also identified 20 genes involved in flagella biosynthesis and assembly by genome-wide expression analysis (Table $\mathrm{S1B})$. According to these observations, mutation in the $r s m A$ and $r s m E$ genes resulted in decreasing motility (Fig. 4a). Bacterial motility and biofilm formation are inversely regulated in Gram-negative bacteria [32]. Interestingly, the results of this work strongly suggest that RsmA and RsmE positively affected biofilm formation (Fig. 4b). Previous study showed that bacterial secondary messenger cyclic diguanylate (c-diGMP) influences biofilm development [33]. Many genes involved in c-di-GMP turn over were regulated by RsmA and RsmE (Table S1). We speculate that RsmA and RsmE may interact with the c-di-GMP signaling pathway to regulate biofilm formation in $P$. fluorescens.

In summary, these results demonstrated that several important intracellular activities and behaviors were regulated by the RsmA family proteins RsmA and RsmE in plant-associated P. fluorescens 2P24. By fine-tuning the concentration of 2,4-DAPG and carbon metabolism in the cells, RsmA and RsmE could contribute to growth advantages of strain $2 \mathrm{P} 24$.

\section{Conclusions}

The plant-associated P. fluorescens 2P24 can colonize root of many crops and protect them from infection by phytopathogens. In this study, our data showed that the regulation of 2,4-DAPG by RsmA and RsmE was complicated and involved in many specific elements. In addition, several important intracellular activities and behaviors, such as growth curve, carbon metabolism, T6SS, the formation of biofilm, and motility were regulated by RsmA and RsmE in strain 2P24. These findings provide a new understanding of the regulatory role of RsmA and RsmE in P. fluorescens.

\section{Methods}

\section{Bacterial strains, plasmids, and growth conditions}

The bacterial strains and plasmids used in this study are listed in Table 1. Escherichia coli was routinely grown in lysogeny broth (LB) medium at $37^{\circ} \mathrm{C}$. Unless otherwise indicated, P. fluorescens $2 \mathrm{P} 24$ and its derivatives were grown in LB medium, King's B medium (KB) [37], or ABM medium [38] at $28^{\circ} \mathrm{C}$. The concentration of antibiotics was added as follows: ampicillin $(50 \mu \mathrm{g} / \mathrm{ml})$, kanamycin $(50 \mu \mathrm{g} / \mathrm{ml})$, tetracycline $(20 \mu \mathrm{g} / \mathrm{ml})$.

\section{Mutant construction}

The phlD in-frame deletion mutant was constructed by allelic exchange mutagenesis [36]. Briefly, upstream and downstream fragments flanking the phlD gene were amplified by PCR using primers phlD-F1-EcoRI/phlDR1-680 and phlD-F2-700/phlD-R2-SalI, respectively. The upstream and downstream PCR products were used as templates in fusion PCR with primers phlD-F1EcoRI/phlD-R2-SalI. Subsequently, the fusing fragment was cloned into the suicide vector p2P24Km [36]. The resulting plasmid p2P24-phlD was introduced into strain $2 \mathrm{P} 24$ and the rsmA rsmE double mutant by electroporation and double-crossover recombination events were selected [39]. Substitution was confirmed by PCR and sequencing.

\section{RNA-seq analysis}

To test the effect of the $r s m A$ and $r s m E$ genes on the transcriptome in $P$. fluorescens 2P24, cells were cultured to early stationary phase $\left(\mathrm{OD}_{600}=1.0\right)$ in $\mathrm{LB}$ medium. Total RNA was conducted using the RNeasy minikit (Qiagen, MD, U.S.A.). The Ambion Turbo DNA-free kit was applied to remove contaminant DNA. After removal of rRNA by using the Ribo-Zero rRNA removal kit (Illumina, CA, U.S.A.), mRNA was used to generate the cDNA library according to NEBNext UltraTM II RNA Library Prep Kit, which was then sequenced using an Illumina HiSeq 2500 platform. High-quality reads were aligned to the P. fluorescens 2P24 genome (GenBank accession no. CP025542). From the resulting alignments, SAMtools version 1.6 [40] was applied to sort the bam file. The differentially expressed genes were identified by performing Cuffdiff version 2.2.1 [41] with a $p$ value smaller than 1e-5. Each sample in the RNA-seq was repeated three times.

\section{Construction of the transcriptional lacZ fusion and measurements of $\beta$-galactosidase activity}

To construct the phlF-lacZ and phlG-lacZ transcriptional fusions, a 700-bp DNA fragment upstream of $p h l F$ and a 540-bp fragment upstream of phlG were cloned separately into pRG970Km [24], ahead of a promoterless lacZ gene, to gain p970Km-phlFp and p970Km-phlGp, respectively. The primers used are listed in Table 1.

Strains carry the lac $Z$ transcriptional fusions were grown in $\mathrm{LB}$ medium with agitation at $28^{\circ} \mathrm{C}$. The bacterial cells were collected by centrifugation and the $\beta$-galactosidase activity was measured using the method as reported previously [42].

\section{Quantification of 2,4-DAPG}

Strain 2P24 and its derivatives were grown in $20 \mathrm{ml} \mathrm{KBG}$ (KB broth supplemented with $2 \%$ glucose) at $28^{\circ} \mathrm{C}$ for 48 h. 2,4-DAPG was extracted from culture supernatant 
Table 1 bacterial strains, plasmids, and oligonucletoides used in this study

\begin{tabular}{|c|c|c|}
\hline Strains, plasmids or oligonucletoide & Relevant characteristics* & Reference or source \\
\hline \multicolumn{3}{|l|}{ Strains } \\
\hline \multicolumn{3}{|l|}{ Pseudomonas fluorescens } \\
\hline $2 \mathrm{P} 24$ & Wild-type, $A p^{r}$ & [16] \\
\hline PM206 & In-frame deletion of retS, $A p^{r}$ & [34] \\
\hline WPM30 & In-frame deletion of $p h / D, A p^{r}$ & This work \\
\hline WPM12 & Double deletion of $r s m A$ and $r s m E, A p^{r}$ & [15] \\
\hline WPM31 & Triple deletion of $r s m A, r s m E$, and $p h / D, A p^{r}$ & This work \\
\hline E. coli DH5a & $\begin{array}{l}\text { supE44 lacU169 ( } \varphi 80 \text { lacZ M15) hsdR17 recA1 } \\
\text { endA1 gyrA96 thi-1 relA1 }\end{array}$ & [35] \\
\hline \multicolumn{3}{|l|}{ Plasmids } \\
\hline $\mathrm{p} 2 \mathrm{P} 24 \mathrm{Km}$ & Sucrose-based counter-selectable plasmid, $\mathrm{Km}^{\mathrm{r}}$ & [36] \\
\hline p2P24Km-phID & Plasmid p2P24Km carrying a deleted phID gene, $\mathrm{Km}^{\mathrm{r}}$ & This work \\
\hline p970Km-phlFp & phIF-lacZ transcriptional fusion, $\mathrm{Km}^{\mathrm{r}}$ & This work \\
\hline p970Km-phlGp & ph/G-lacZ transcriptional fusion, $\mathrm{Km}^{\mathrm{r}}$ & This work \\
\hline p415-phlG & pRK415 containing the ph/G gene, Tet $^{r}$ & [22] \\
\hline pHSG299 & Cloning vector, $\mathrm{Km}^{\mathrm{r}}$ & TaKaRa \\
\hline Oligonucletoides & Sequence $\left(5^{\prime}-{ }^{\prime} 3\right)^{\text {a }}$ & Comment \\
\hline phID-F1-EcoRl & AAGAATTCATGGCGATGGTGCGCCT & \multirow{4}{*}{$\begin{array}{l}\text { phID null mutant } \\
\text { construction }\end{array}$} \\
\hline phID-R1-680 & GAATTTCCGTCCGCCTGTATGGAACATGAAACCCGTGCACGATGTCACA & \\
\hline phID-F2-700 & TGTGACATCGTGCACGGGTTTCATGTTCCATACAGGCCGGACGGAAAATTC & \\
\hline phlD-R2-Sall & AAGTCGACCAGGCTGGTGATCAATG & \\
\hline phIG-PFBamHI & TAGGATCCAGTTGCA CCAACCGAGC & \multirow[t]{2}{*}{ ph/G-lacZ transcriptional fusion } \\
\hline phlG-PRBamHI & ATGGATCCGGCACGCTGATCTTCGAGC & \\
\hline phIF-PFBamHI & ACGGATCCAGATCTTAAGGGTTTCTAT & phlF-lacZ transcriptional fusion \\
\hline phIF-PRBamHI & GTGGATCCATAAGGATTGGTGCAG & \\
\hline
\end{tabular}

*Ap, ampicillin; Km, kanamycin; Tet, tetracycline

a Restriction site inserted in the primer for the cloning strategy are underlined

and quantitatively analyzed according to the method described previously [43].

\section{Swimming motility assay}

Overnight LB culture was inoculated, and transferred at 1: 1000 to $2 \mathrm{ml}$ fresh LB medium, and then grown at $28^{\circ} \mathrm{C}$ until it reached an OD600 of 0.8. Two microliters of the cultures were spotted on soft LB plates $(0.3 \%$ agar). The plates were inoculated at $28^{\circ} \mathrm{C}$ for $24 \mathrm{~h}$.

\section{Biofilm formation assay}

A biofilm detection experiment was performed as reported previously [44]. In brief, overnight bacterial culture was transferred to a 2-ml EP tube containing $1 \mathrm{ml}$ $\mathrm{LB}$ medium at an $\mathrm{OD}_{600}$ of 0.5 and cultured statically at $28^{\circ} \mathrm{C}$ for $2 \mathrm{~d}$. Crystal violet $(0.1 \%)$ was used to stain biofilm adhered to the tubes for $15 \mathrm{~min}$. The tubes were washed gently three times with $\mathrm{ddH}_{2} \mathrm{O}$, and the remaining crystal violet was fully dissolved in $200 \mu$ of $95 \%$ ethanol and the absorbance was detected at $570 \mathrm{~nm}$.

\section{Western blot analysis}

P. fluorescens cells were grown in $\mathrm{LB}$ at $28^{\circ} \mathrm{C}$ for $12 \mathrm{~h}$ and 1-ml samples were taken. Cells were then collected by centrifugation, re-suspended in PBS buffer, and lysed by sonication. The protein in crude lysates was quantified using the Bradford protein assay (Bio-Rad, CA, U.S.A.). Samples were boiled before being loaded onto $12 \%$ sodium dodecyl sulfate polyacrylamide (SDS-PAGE) gels. Proteins were then transferred onto a polyvinylidene fluoride membrane (PVDF) (Millipore, MA, U.S.A.). Blots were washed with PBS containing 0.05\% Tween-20 and probed with an anti-Hcp1 antibody (1: 2000). Anti-RNA polymerase monoclonal antibody (1: 2000) (Neoclone, WI, U.S.A.) was used as a control. Signals were then developed using the chemiluminescence detection kit (Thermo Fisher, MA, U.S.A.).

\section{T6SS competition assays}

Competition assays were performed as previously described [45]. Overnight bacterial cultures were adjusted 
to $\mathrm{OD}_{600}$ of 1 in PBS solution and mixed in a 1:1 ratio [P. fluorescens-E. coli (pHSG299) as prey]. Bacteria were spotted on LB agar plates to co-culture at $28^{\circ} \mathrm{C}$ for $5 \mathrm{~h}$. The competition was then quantified by counting colony-forming units on antibiotic selection.

\section{Statistical analysis}

Data were tested for normality and analyzed using unpaired Student's $t$ test. Asterisks indicated $P$ values (", $P<0.05$; ",$P<0.01$ ), and results were presented as the mean standard deviation. Each experiment was performed three times in similar conditions.

\section{Supplementary information}

Supplementary information accompanies this paper at https://doi.org/10. 1186/s12866-020-01880-x.

Additional file 1: Table S1. The genes regulated by the RsmA and

RsmE proteins

Additional file 2: Figure S3. a A Western blot analysis of Hcp1 protein level in 2P24 (lane 1), the rsmA rsmE double mutant (lane 2), and the rets mutant (lane 3). (from left to right: lane 1 to 3). Figure S3 b Western blot analysis of RNA polymerase beta protein level (as a loading control) in 2P24 (lane 1), the rsmA rsmE double mutant (lane 2), and the rets mutant (lane 3). (from left to right: lane 1 to 3 )

\section{Abbreviations}

2,4-DAPG: 2,4-diacetylphloroglucinol; sRNA: small non-coding RNA; UAS: upstream activating sequence; PG: phlotoglucinol;

MAPG: monoacetylphloroglucinol; T6SS: type six secretion system; RNAseq: RNA sequencing; DEGs: differentially expressed genes; c-di-GMP: cyclic diguanylate

\section{Acknowledgments}

We thank Dr. Joseph Mougous for providing the Hcp1 antibody and Dr. Ching-Hong Yang for his thoughtful suggestions about the project.

\section{Authors' contributions}

$X W, Q Y$, and $L Q Z$ designed the project. $Y Z, B Z$, and $X W$ carried out the experiments. YZ, BZ, HW, QY, and XW participated in the data analysis and wrote the manuscript. All authors read and approved the final manuscript.

\section{Funding}

This project was supported by grants from the Chinese National Natural Science Foundation (31760533), the National Key Research and Development Program of China (2017YFD02011083), the Science and Technology Major Project of Guangxi (AA17204041), and the Natural Science Foundation of Guangxi (2017GXNSFAA198341).

The funding bodies had no role in study design, data collection and analysis, interpretation of data, decision to publish, or preparation of the manuscript.

\section{Availability of data and materials}

The genome sequence of Pseudomonas fluorescens 2P24 has been submitted to GenBank with accession number CP025542. The datasets used and/or analyzed during this study available from the corresponding author on reasonable request.

\section{Ethics approval and consent to participate}

Not applicable.

\section{Consent for publication}

Not applicable.

\section{Competing interests}

The authors declare that they have no competing interests.
Received: 11 May 2020 Accepted: 26 June 2020

Published online: 02 July 2020

\section{References}

1. Haas D, Défago G. Biological control of soil-borne pathogens by fluorescent pseudomonads. Nat Rev Microbiol. 2005;3:307-19.

2. Heeb S, Haas D. Regulatory roles of the GacS/GacA two-component system in plant-associated and other gram-negative bacteria. Mol Plant-Microbe Interact. 2001;14:1351-63.

3. Zuber S, Carruthers F, Keel C, Mattart A, Blumer C, Pessi G, Gigot-Bonnefoy C, Schnider-Kell U, Heeb S, Reimmann C, Haas D. GacS sensor domains pertinent to the regulation of exoproduct formation and to the biocontrol potential of Pseudomonas fluorescens CHAO. Mol Plant-Microbe Interact. 2003;16:634-44.

4. Romeo T, Gong M, Liu MY, Brun-Zinkernagel AM. Identification and molecular characterization of csrA, a pleiotropic gene from Escherichia coli that affects glycogen biosynthesis, gluconeogenesis, cell size, and surface properties. J Bacteriol. 1993:175:4744-55.

5. Wei BL, Brun-Zinkernagel AM, Simecka JW, Prüss BM, Babitzke P, Romeo T. Positive regulation of motility and $\mathrm{FlhDC}$ expression by the RNA-binding protein CsrA of Escherichia coli. Mol Microbiol. 2001;40:245-56.

6. Brencic A, Lory S. Determination of the regulon and identification of novel mRNA targets of Pseudomonas aeruginosa RsmA. Mol Microbiol. 2009;72: 612-32.

7. Blumer C, Heeb S, Pessi G, Haas D. Global GacA-steered control of cyanide and exoprotease production in Pseudomonas fluorescens involves specific ribosome binding sites. Proc Natl Acad Sci U S A. 1999;96:14073-8.

8. Pessi G, Williams F, Hindle Z, Heurlier K, Holden MTG, Cámara M, Haas D, Williams P. The global posttranscriptional regulator RsmA modulates production of virulence determinants and $\mathrm{N}$-acylhomoserine lactones in Pseudomonas aeruginosa. J Bacteriol. 2001;187:276-85.

9. Kay E, Dubuis C, Haas D. Three small RNAs jointly ensure secondary metabolism and biocontrol in Pseudomonas fluorescens CHAO. Proc Natl Acad Sci U S A. 2005;102:17136-41.

10. Kay E, Humair B, Denervaud V, Riedel K, Spahr S, Eberl L, Valverde C, Haas D. Two-GacA-dependent small RNAs modulate the quorum-sensing response in Pseudomonas aeruginosa. J Bacteriol. 2006;188:6026-33.

11. Lapouge $K$, Schubert M, Allain FH-T, Haas D. Gac/Rsm signal transduction pathway of $\gamma$-proteobacteria: from RNA recognition to regulation of social behaviour. Mol Microbiol. 2008;67:241-53.

12. Huertas-Rosales Ó, Ramos-González MI, Espinosa-Urgel M. Self-regulation and interplay of Rsm family proteins modulate the lifestyle of Pseudomonas putida. Appl Environ Microbiol. 2016;82:5673-86.

13. Morris ER, Hall G, Li C, Heeb S, Kulkarni RV, Lovelock K, Silistre H, Messina M, Camara M, Emsley J, Williams P, Searle MS. Structural rearrangement in an RsmA/CsrA ortholog of Pseudomonas aeruginosa creates a dimeric RNAbinding protein. RsmN Structure. 2013;21:1659-71.

14. Ferreiro MD, Nogales J, Farias GA, Olmedilla A, Sanjuán J, Gallegos MT. Multiple CrsA proteins control key virulence traits in Pseudomonas syringae pv. tomato DC3000. Mol. Plant Microbe Interact. 2018;31:525-36.

15. Zhang Y, Zhang B, Wu X, Zhang LQ. Characterization the role of GacAdependent small RNAs and RsmA family proteins on 2,4diacetylphloroglucinol production in Pseudomonas fluorescens 2P24. Microbiol Res. 2020;233:126391.

16. Wei HL, Wang Y, Zhang LQ, Tang WH. Identification and characterization of biocontrol bacterial strain 2P24 and CPF-10. Acta Phytopathol Sin. 2004;34: 80-5.

17. Bangera MG, Thomashow LS. Identification and characterization of a gene cluster for synthesis of the polyketide antibiotic 2,4-diacetylphloroglucinol from Pseudomonas fluorescens Q2-87. J Bacteriol. 1999;181:3155-63.

18. Zha W, Rubin-Pitel SB, Zhao H. Characterization of the substrate specificity of PhID: a type III polyketide synthase from Pseudomonas fluorescens. J Biol Chem. 2006:281:32036-47.

19. Schnider-Keel U, Seematter A, Maurhofer M, Blumer C, Duffy B, GigotBonnefoy C, Reimmann C, Notz R, Défago G, Haas D, Keel C. Autoinduction of 2,4-diacetylphloroglucinol biosynthesis in the biocontrol agent Pseudomonas fluorescens $\mathrm{CHAO}$ and repression by the bacterial metabolites salicylate and pyoluteorin. J Bacteriol. 2000;182:1215-25.

20. Abbas A, McGuire JE, Crwoley D, Baysse C, Dow M, O'Gara F. The putative permease PhIE of Pseudomonas fluorescens F113 has a role in 2,4- 
diacetylphloroglucinol resistance and in general stress tolerance. Microbiology. 2004;150:2443-50.

21. Haas $D$, Keel C. Regulation of antibiotic production in root-colonizing Pseudomonas spp. and relevance for biological control of plant disease. Annu Rev Phytopathol. 2003;41:117-53.

22. Yan X, Yang R, Zhao RX, Han JT, Jia WJ, Li DY, Wang Y, Zhang N, Zhang LQ He YX. Transcriptional regulator PhIH modulates 2,4-diacetylphloroglucinol biosynthesis in response to the biosynthetic intermediate and end product. Appl Environ Microbiol. 2016;83:e01419-7.

23. Bernal P, Allsopp LP, Filloux A, Llamas MA. The Pseudomonas putida T6SS is a plant warden against phytopathogens. ISME J. 2017;11:972-87.

24. Allsopp LP, Wood TE, Howard SA, Maggiorelli F, Nolan LM, Wettstadt S, Filloux A. RsmA and AmrZ orchestrate the assembly of all three type VI secretion systems in Pseudomonas aeruginosa. Proc Natl Acad Sci U S A. 2017:114:7707-12.

25. Hood RD, Singh P, Hsu F, Güvener T, Carl MA, Trinidad RRS, Silverman JM, Ohlson BB, Hicks KG, Pleel RL, Li M, Schwarz S, Wang WY, Merz AJ, Goodlett DR, Mougous JD. A type VI secretion system of Pseudomonas aeruginosa targets a toxin to bacteria. Cell Host Microbe. 2010;7:25-37.

26. Zhang B, Zhao H, Wu X, Zhang LQ. The oxidoreductasee DsbA1 negatively influences 2,4-diacetylphloroglucinol biosynthesis by interfering the function of Gcd in Pseudomonas fluorescens 2P24. BMC Microbiol. 2020;20:39.

27. Wu XG, Duan HM, Tian T, Yao N, Zhou HY, Zhang LQ. Effect of the hfa gene on 2,4-diacetylphloroglucinol production and the Pcol/PcoR quorumsensing system in Pseudomonas fluorescens 2P24. FEMS Microbiol Lett. 2010; 309:16-24.

28. Wu, X., Liu, J., Zhang, W., Zhang, L.Q., 2012. Multiple-level regulation of 2,4diacetylphloroglucinol production by the sigma regulator PsrA in Pseudomonas fluorescens 2P24. PloS ONE. e50149.

29. Yan $\mathrm{Q}$, Wu XG, Wei HL, Wang HM, Zhang LQ. Differential control of the $\mathrm{Pcol} / \mathrm{PcoR}$ quorum-sensing system in Pseudomonas fluorescens $2 \mathrm{P} 24$ by sigma factor RpoS and the GacS/GacA two-component regulatory system. Microbiol Res. 2009;164:18-26.

30. Ge Y, Lee JH, Liu J, Yang H-W, Tian Y, Hu B, Zhao Y. Homologues of the RNA binding protein RsmA in Pseudomonas syringae pv. tomato DC3000 exhibit distinct binding affinities with non-coding small RNAs and have distinct roles in virulence. Mol Plant Pathol. 2019;20:1217-36.

31. Reimmann C, Valverde C, Kay E, Haas D. Posttranscriptional repression of GacS/GacA-controlled genes by the RNA-binding protein RsmE acting together with RsmA in the biocontrol strain Pseudomonas fluorescens CHAO. J Bacteriol. 2005;187:276-85.

32. O'Toole GA, Kolter R. Flagellar and twitching motility are necessary for Pseudomonas aeruginosa biofilm development. Mol Microbiol. 1998;30: 295-304.

33. Römling U, Galperin MY, Gomelsky M. Cyclic di-GMP: the first 25 years of a universal bacterial second messenger. Microbiol Mol Biol Rev. 2013;77:1-52.

34. Liu J, Zhang W, Wu X, Zhang L. Effect of retS gene on biosynthesis of 2,4diacetylphloroglucinol in Pseudomonas fluorescens 2P24. Acta Microbiol Sin. 2013;53:118-26.

35. Sambrook, J., Fritsch, E.F., Maniatis, T., 1989. Molecular cloning: a laboratory manual, 2nd ed. Cold Spring Harbor Laboratory, Cold Spring Harbor, NY.

36. Zhang $Y$, Zhang $Y$, Zhang $B$, Wu X, Zhang LQ. Effect of carbon sources on production of 2,4-diacetylphloroglucinol in Pseudomonas fluorescens 2P24. Acta Microbiol Sin. 2018;58:1202-12.

37. King EO, Ward MK, Raney DE. Two simple media for the demonstration of pyocyanin and fluorescein. J Lab Clin Med. 1954;44:301-7.

38. Chilton MD, Currier TC, Farrand SK, Bendich AJ, Gordon MP, Nester EW. Agrobacterium tumefaciens DNA and PS8 bacteriophage DNA not detected in crown gall tomors. Proc Natl Acad Sci U S A. 1974;71:3672-6.

39. Smith, A.W., Iglewski, B.H., 1989. Transformation of Pseudomonas aeruginosa by electroporation. Nucleic acids res.17, 10509.

40. Li H, Handsaker B, Wysoker A, Fennell T, Ruan J, Homer N, Marth G, Abecasis G, Durbin R, 1000 Genome Project Data Processing Subgroup. The sequence alignment/map format and SAMtools. Bioinformatics. 2009;25: 2078-9.

41. Trapnell C, Williams BA, Pertea G, Mortazavi A, Kwan G, van Baren MJ, Salzberg SL, Wold BJ, Pachter L. Transcript assembly and quantification by RNA-seq reveals unannotated transcripts and isoform switching during cell differentiation. Nat Biotechnol. 2010;28:511-5.

42. Miller JH. Experiments in molecular genetics. Cold Spring Harbor, NY: Cold Spring Harbor Laboratory; 1972.
43. Shanahan P, O'Sullivan DJ, Simpson P, Glennon JD, O'Gara F. Isolation of 2,4diacetylphloroglucinol from a fluorescent pseudomonad and investigation of physiological parameters influencing its production. Appl Environ Microbiol. 1992;58:353-8.

44. Wei HL, Zhang LQ. Quorum-sensing system influences root colonization and biological control ability in Pseudomonas fluorescens 2P24. Antonie Van Leeuwenhoek. 2006;89:267-80.

45. Hachani A, Lossi NS, Filloux A. A visual assay to monitor T6SS-mediated bacterial competition. J Vis Exp. 2013;73:e50103.

\section{Publisher's Note}

Springer Nature remains neutral with regard to jurisdictional claims in published maps and institutional affiliations.
Ready to submit your research? Choose BMC and benefit from:

- fast, convenient online submission

- thorough peer review by experienced researchers in your field

- rapid publication on acceptance

- support for research data, including large and complex data types

- gold Open Access which fosters wider collaboration and increased citations

- maximum visibility for your research: over $100 \mathrm{M}$ website views per year

At $\mathrm{BMC}$, research is always in progress.

Learn more biomedcentral.com/submissions 